\title{
THE ORIGINS OF THE 1852 LOCK-OUT IN THE BRITISH ENGINEERING INDUSTRY RECONSIDERED*
}

The engineers' lock-out of 1852 is just one of those historical events which, while receiving extensive coverage and being long pondered over, remain to this day a bone of contention. In terms of scale and in the sophistication of the tactics employed, it "was the first of a new class of strikes or lock-outs". ${ }^{1}$ It aroused more sustained interest than any previous industrial dispute. $^{2}$ It stimulated "a discussion of the strike by the press, so comprehensive and exhaustive that a reproduction of the newspaper articles would fill volumes". ${ }^{3}$ At this time, the only other trade unions of any appreciable size were still less than half the strength of the Amalgamated Society of Engineers. Some earlier combinations had been larger, but they had been formed solely in relation to specific strikes and, as such, were ephemeral in character. The mass movements of 1830-34 generally rested upon the precarious financial foundations of irregular levies. The Webbs concluded that a "trade society which [. . . ] could count on a regular income of $£ 500$ a week was without precedent." 4

To counter this new phenomenon the employers responded with innovations of their own. During the lock-out, they hired outside assistance in the form of the lawyer Sidney Smith to co-ordinate activities. The Manchester wing of the engineering employers went so far as to tie its members 5 with what the Northern Star termed "that strongest pledge of commercialists, a money deposit, to be forfeited in the event of withdrawal". 6 While, of course, the relative economic power of the protagonists was a crucial factor in the outcome of the lock-out, it was not merely a

* The author wishes to express his appreciation to a number of departmental colleagues for their helpful comments and, in particular, in this regard, to Ivan Waddington.

1 Th. Hughes, Account of the Lock-Out of engineers, \&c. 1851-2 (Cambridge, 1860), p. 5.

2 S. and B. Webb, The History of Trade Unionism, revised ed. (London, 1920), p. 215.

3 W. Pole, The Life of Sir William Fairbairn (London, 1877), p. 324.

4 S. and B. Webb, op. cit., p. 214, note to p. 213.

5 Hughes, op. cit., p. 12.

6 Northern Star, January 10, 1852. 
struggle of economic attrition. Far more than any previous dispute, the power of the media was recognised and exploited. Both parties vied through the press to persuade what is vaguely termed "public opinion" of the merits of their cause.

The following reappraisal will focus upon one aspect of the origins of this struggle, namely, the disagreement surrounding the identification of the central issues which precipitated the crisis. Of particular relevance is the degree to which the ASE was prepared to pursue its policy of exclusiveness. The exercise is not only undertaken with the aim of clarifying the historical record, but is also an attempt to probe the causes underlying the inadequacy of previous accounts. For here, it will be argued, the controversy surrounding the origins of the lock-out does not stem from the ambiguity of the available data. Its source lies in the subjectivity of the prime contributors. As such it provides a salutory demonstration of the distorting effects of ideological preoccupations. It is proposed, therefore, to look afresh at the origins of the lock-out with a view to evolving an explanation which is more compatible with the available evidence.

In the post-Second World War period two polar versions have emerged, as represented by the views of J. B. Jefferys ${ }^{7}$ and Henry Pelling. ${ }^{8}$ Jefferys, the official historian of the Engineers, is in no doubt as to the main issues of the dispute. He explains away confusion in terms of

Mis-statements by the Manchester employers [...] regarding the claims of the engineers $[. .$.$] and in particular making much of the "discharge of$ labourers from machines," [...].

the employers were doing everything to win public opinion and to extend the lock-out. By their clever play with the question of labourers on machines they had convinced a wide section of opinion that this was the main demand of the Society. The real demands regarding overtime and piece-work were pushed in to the background. ${ }^{9}$

In contradistinction, Pelling unequivocally states:

The employers, working in concert, locked out their tradesmen when they refused to accept an increase in the number of unskilled men in the shops. ${ }^{10}$

There exists, then, to put it delicately, a divergence of opinion; one which stretches back to the origins of the lock-out itself. The earlier efforts of the Webbs $^{11}$ and Thomas Hughes ${ }^{12}$ to accommodate these conflicting versions

7 J. B. Jefferys, The Story Of The Engineers 1800-1945 (London, n.d., reprinted 1970).

8 H. Pelling, A History of British Trade Unionism (Harmondsworth, 1963).

9 Jefferys, op. cit., pp. 37-39. Italics added.

${ }_{10}$ Pelling, op. cit., p. 51.

11 S. and B. Webb, op. cit., pp. 214-15.

12 Hughes, op. cit., p. 13. 
leaned towards explanations couched in terms of an "unfortunate misunderstanding". While seemingly less tendentious, this conciliatory approach leaves much to be explained.

By way of an opening shot it may be pointed out that Jefferys's stated position does not entirely accord with even some of his own presented material. Nevertheless, he does provide a useful source on which to draw when mounting a re-interpretation. In contrast, Pelling's substantive contribution to the debate barely warrants serious consideration. It is both cursory and misleading. Admittedly, a study as ambitious as Pelling's cannot conceivably cover developments in any depth, but this recognition hardly exonerates him from changes of gross partiality. However, despite its brevity, his position does provide an illuminating counterpoint, and it is this, plus his prominence as a labour historian, which secures his inclusion.

In a recent article Keith Burgess has attempted to resolve the discrepancy between these two interpretations. ${ }^{13} \mathrm{He}$ correctly points out that the entire confrontation and subsequent accounts of the lock-out have been confounded by the imbrication of a local dispute and a national campaign. He argues that the dismissal of "illegal men" was a local issue specific to the Oldham firm of Hibbert and Platt, ${ }^{14}$ while the abolition of piece-work and systematic overtime were the twin demands of the Society. He writes:

The facts suggest that the official leadership of the Engineers' found the "illegal men" issue rather an embarrassment. This explains its repudiation by the Executive and its exclusion from the official campaign. ${ }^{15}$

Unfortunately, the hoped for clarification ${ }^{16}$ does not transpire. While providing a great deal of additional background material, Burgess neglects much evidence of direct relevance to his stated task. Essentially, he ploughs the same furrow as Jefferys. He is at one with the latter when he writes:

From the beginning, official union policy had confined itself to opposing systematic overtime and piece-work. The misrepresentation of the facts by the Association of Employers was important in that it won public sympathy and gained new members. ${ }^{17}$

The very neatness of Burgess's account belies the complexities of the aetiology of the lock-out. His rendition conveys a flat, static image of the parties involved. The state of the debate is such as to compel the retrac-

13. Burgess, "Trade Union Policy and the 1852 Lock-Out in the British Engineering Industry", in: International Review of Social History, XVII (1972).

14 Ibid., p. 656.

15 Ibid., p. 655.

16 Ibid., p. 645.

17 Ibid., pp. 656-57. Italics added. 
ing of a well-worn path, which, despite its familiarity, contains many anomalies disdained by previous travellers.

After a prolonged period of negotiations riven by sectional interests, the ASE was finally established on January 6,1851 . In terms of the breadth of the original concept, its inangural form was somewhat less than impressive. It mustered a meagre five thousand members, ${ }^{18}$ a figure rather smaller than its parent body, the "Old Mechanics". ${ }^{19}$ For the first few months, it eked out a precarious existence, its survival still very much in doubt. Gradually, however, the rebel branches succumbed and a number of small societies were admitted. Confidence in the venture was restored to a degree whereby the Webbs could write that "by October Newton and Allan were at the head of a united society of 11,000 members paying 1s. per week each, the largest and most powerful Union that had ever existed in the engineering trades, and far exceeding in membership, and still more in annual income, any other trade society of the time." 20

The main grievance of the membership was perceived as being the constant threat of redundancy. ${ }^{21}$ It was to assuage this fear that the ASE primarily dedicated its energies. In the early months the initiative was taken at plant and district level, Lancashire being particularly prominent in this regard. As success followed upon success, demands for more conspicuous leadership grew apace. The decision of the Executive to eschew caution and submit to these pressures can be seen in retrospect to have been of immense significance. The attempt to implement trade policy at the national level precipitated a train of events which was destined to culminate in the lock-out.

The eye of that, as yet distant, storm was the Oldham firm of Messrs. Hibbert, Platt and Sons. At the time it was in all probability the largest engineering firm in the world, ${ }^{22}$ employing between 1,600 and 1,700 men $^{23}$ in the manufacture of textile machinery. Its capital assets exceeded $£ 150,000$ and during 1851 secured profits of $£ 45,000 .{ }^{24}$ The firm was a pioneer in capital-intensive techniques, using mostly Whitworth tools. ${ }^{25}$ These advanced industrial conditions made the issues of piece-work,

18 Jefferys, op. cit., p. 29.

19 Their official title was "The Journeymen Steam Engine and Machine Makers and Millwrights' Friendly Society".

${ }^{20} \mathrm{~S}$. and B. Webb, op. cit., p. 213.

21 The Operative, April 12, 1851.

22 Ibid., May 31.

23 The Times, January $1,1852$.

24 Ibid., January 19, quoted by Burgess, “Trade Union Policy”, loc. cit., p. 650.

25 Thomas Wood in Useful Toil, ed. by J. Burnett (London, 1974), p. 310. 
overtime and "illegal men" particularly acute. ${ }^{26}$ Some insight into the atmosphere that pervaded the firm a few years earlier is provided by one Thomas Wood, a journeyman engineer. He described it as "a place where no favour was shown [. . .]. I saw many start that were paid off the first day, some at even a shorter trial. [...] Men in large shops are not troubled with a variety of work, but had one class of work and special tools. The men soon became expert and turned out a large quantity of work with the requisite exactness without a little of the thought required of those who work in small shops where fresh work continually turns up". ${ }^{27}$ Given these circumstances, it was hardly by any trick of fate that this firm found itself at the front-line. As Burgess has clearly demonstrated in an earlier paper, there exists a strong correlation between firms participating in the lock-out and advanced technology. ${ }^{28}$

According to Thomas Hughes the troubles at Hibbert and Platt stretched back to 1850.29 The firm consisted of two distinctively organised plants, known as the "Old" and the "New". In the "New" the machines were operated by qualified mechanics, while the "Old" factory employed unapprenticed labour supervised by a few skilled men. ${ }^{30}$ The spread of the latter system and the feelings this aroused was to be made a central issue in the coming national struggle. On April 10, 1851, a meeting was held at Oldham. The Operative summarised the demands as follows:

The employment of mechanics instead of labourers on machines - such as Boring, Planing, Slotting and Shaping Machines. The employment of none but men who have served an apprenticeship to trade - the abolition of systematic overtime and piece-work - and the discharge of such men as have by their unjust proceedings rendered themselves obnoxious to the trade through having oppressed its members. ${ }^{31}$

These demands were accompanied by a strike threat to come into effect on April 21. However, the employers agreed to negotiate, and so the ultimatum was withdrawn. ${ }^{32}$

The Oldham men sent a message to London requesting the presence of William Newton as a mediator. Newton reports:

26 Jefferys, op. cit., p. 35.

27 Wood, loc. cit., p. 310 . Wood worked at Hibbert and Platt for thirteen to fourteen months from the summer of 1845 .

28 Burgess, "Technological Change and the 1852 Lock-Out in the British Engineering Industry", in: International Review of Social History, XIV (1969).

29 Hughes, op. cit., p. 9.

30 The Operative, May 3, 1851.

31 Ibid.

32 Burgess, “Trade Union Policy”, loc. cit., p. 652. 
I did not go down without previously consulting the executive council, and the council were decidedly of the opinion that the funds of the society should not be used in getting the men discharged from the machines. ${ }^{33}$

Hughes states that the Executive Council met on May 5, 1851. They resolved that they were

prepared to assist the Oldham members to the extent of their power in abolishing systematic overtime, but cannot consent to assist them in removing the unskilled workmen from the self-acting machines. ${ }^{34}$

Jefferys, by way of variation, writes that the Executive Council met on May 4 to discuss the question and expressed full support for the men on all demands, but resolved that they could not "consent to the men leaving their situations because they may not at present be able to obtain the working of the machines". 35

A meeting at Oldham on Tuesday May 6 heard a deputation report that Platt had agreed to the discontinuation of overtime, to dispense with "illegal hands" and, so it was understood, to the dismissal of the piecemaster Michael Bernard. However, he was opposed to the discharge of those who had long been engaged on the working of self-acting machines and their replacement by mechanics, and he would not concede without a struggle. ${ }^{36} \mathrm{He}$ argued that it was not possible for him to "give up those machines to mechanics; the mechanics had given them up years ago, and the practice of employing labourers was held in every district in the county, and he could not give way". Platt's manager, a Mr Richardson, was critical of "the manner in which the workmen had conducted themselves towards these machines, always leaving them in apparent disgust when an opportunity offered to obtaining employment at another department of trade". ${ }^{37}$

A member of the deputation, a Mr Rye, confessed that we "had been somewhat remiss in our duty, by not looking after them as we ought to have done [...]. The deputation acknowledged that although there had been a feeling amongst the workmen against working these machines; but since they had become of such universal practice, and since so much of the best part of the work was being performed at them, there was a feeling in the contrary directions [...]. they must either regain these machines for the mechanics, or improvements would go on until all was done by

33 Supplement to The Operative, December 30, 1851.

34 Minute book of the Executive Council, quoted by Hughes, op. cit., p. 10.

35 Jefferys, op. cit., p. 35 . Source not indicated, italics added. I was unable to determine whether these statements derive from two separate meetings or were the products of the same meeting and a confusion of dates.

36 The Operative, May 17, 1851.

37 Ibid. 
labourers."38 More specifically, the men claimed that Hibbert and Platt were compelling them "to learn labourers, at $15 \mathrm{~s}$. a-week, so as to take our situations, when they were instructed, with a view, as they have expressed it, that they should conduct the works with a few leading hands, labourers and apprentices". ${ }^{39}$

On Wednesday May 7 another meeting of the Oldham men was held, at which Newton was present. He advised them to send a further deputation to Platt, and he offered to accompany it. The following resolution was passed:

That Planing, Slotting, Shaping and Boring Machines in Messrs. Hibbert and Platt's establishment, be restored to the mechanics on, or before Friday evening next.

Subsequently, the deputation softened this line by suggesting to Platt that all new machines erected, or as old ones were vacated, that they should be filled up with the mechanics. Platt countered these proposals with two propositions of his own.

1. That all tools at present worked by labourers should continue to be so worked.

2. That all new planing, slotting, shaping and boring machines, should be worked by boys and mechanics.

At the next meeting the men reacted to this deputation's report by passing the following resolutions.

1. That the whole of the planing, slotting, shaping and boring machines be at the service of mechanics.

2. That in the event of Messrs. Hibbert and Platt conceding our request that the removal of labourers from these take place as soon as the hands can be conveniently obtained.

3. That in the event of Messrs. Hibbert and Platt refusing to comply with our request, that the deputation on our behalf tender in our notice, to leave their employ on Saturday the 17th inst.

Platt responded with further concessions.

1. That in future all planing, slotting, shaping and boring machines, should be worked either by mechanics or apprentices to be taken up by them as they become vacant.

2. That the labourers at present employed upon them be not unduly interfered with before Whitsuntide 1852, when the machines should entirely fall into the hands of the mechanics; but if any of the labourers are discharged, or the machines otherwise become vacant, the vacancies shall be filled by mechanics as they occur.

38 Ibid.

39 The Times, January 14, 1852. 
Reporting back on Friday May 9, Newton argued that "Platt had made considerable concessions, and he would advise the meeting to accept them." 40 But, after a discussion lasting $5 \frac{1}{2}$ hours, finishing after midnight, ${ }^{41}$ the men, by 450 to 120 , voted for "nothing but the full demands", and strike notices were handed in for May $17.4^{42}$

Newton returned to London for an Executive Council meeting on May 13. The minute book records:

Mr. Newton stated to the Council that he had been to Oldham, but had not been able to mediate successfully between the workmen and Messrs. Hibbert, Platt and Son. Mr. John Platt had made certain propositions, and he had advised the men to accept them, but they had refused, when it was "Resolved, - That in the opinion of this Council the offer of Mr. John Platt ought to be accepted, and the Oldham men will not be justified in refusing them; and that Mr. Newton, of London, and Messrs. Norbury and Hemm, of Manchester, be deputed to the workmen of Messrs. Hibbert and Platt to prevail on them not to leave their situations, but to accept the proposals of Mr. Platt." 43

On the same day Platt arranged a meeting of the employers in Manchester to ascertain whether or not they would be prepared to enter "into a general resolution to resist". ${ }_{44}$ While the gathering pledged support in helping Hibbert and Platt resist any interference in the management of their business, ${ }^{45}$ as Jefferys put it, "a strong competitive spirit prevented any real enthusiasm". ${ }^{6}$ Nevertheless, an Association of Employers was formed with an initial membership of 21 firms throughout Lancashire. ${ }^{47}$

The official union deputation met with Platt on May 16. Agreement was reached $^{48}$ when Platt made the additional concession to dismiss the labourers by Christmas of that year. That evening a meeting of 800 men overwhelmingly voted for acceptance. ${ }^{49} \mathrm{~A}$ further snag arose concerning the position of the piece-master Michael Bernard, The men had understood that Platt had agreed to his dismissal, but Platt's interpretation was that he had agreed that this man "should be reduced in authority to the

40 The Operative, May 17, 1851.

41 Jefferys, op. cit., pp. 35-36.

42 The Operative, May 17, 1851.

43 Quoted by Hughes, op. cit., pp. 10-11. Norbury and Hemm were members of the remnants of the "Old Mechanics", who were just about to amalgamate with the ASE.

44 The Times, January 1, 1852.

45 The Operative, May 24, 1851.

46 Jefferys, op. cit., p. 36.

47 The Operative, May 24, 1851, quoted by Burgess, "Trade Union Policy", p. 654.

48 The Operative, May 24, 1851.

49 Ibid. 
position of an ordinary workman, but he did not consider that he was called upon to discharge him". ${ }^{50}$ The final agreement was as follows:

1. That in future all planing, shaping and boring machines, at the workshop of the undersigned be worked either by mechanics or apprentices, to be taken up by them as they become vacant.

2. That the labourers at present employed on those machines be not unduly interfered with before Christmas, 1851, when the machines shall fall entirely into the hands of the mechanics; but if any of the labourers are discharged, or the machines otherwise become vacant, the vacancies shall be filled up by the mechanics as they occur.

3. That Michael Bernard have taken from him all authority over the workmen in our employ, and that all illegal hands be discharged. We further say that we disapprove of the practices alleged against Bernard and pledge ourselves that they shall not again be repeated.

4. That systematic overtime be abolished, and any claims for exception decided by the district committee.

5. That if the majority of legal shops, in the same line of business, refuse to concede the above requests, at the end of three years from the date of these resolutions the question be again open for discussion.

6. $[\ldots]^{51}$

This agreement was maintained until mid July, when "another deputation demanded the unconditional discharge of Bernard and of other workmen [...] on the ground that we [Hibbert and Platt] had not complied with the foregoing arrangement". This led to a strike, involving 1,600 to $1,700 \mathrm{men}$, which closed the whole establishment. ${ }^{52}$ While the strikers did not receive the support of the Society, ${ }^{53}$ Platt was "compelled to comply with their demand".54

A string of successful local initiatives, of which Oldham was only the most impressive, excited more ambitious aspirations. ${ }^{55}$ Demands began to grow for concerted action in the pursuit of the resolutions of the Birmingham conference of September 1850 relating to systematic overtime and piece-work. ${ }^{56}$ The Executive had been slow to move on these issues, but pressure was becoming irresistible. On July 11 they sent out a circular

50 Ibid.

51 The Times, January 1, 1852.

52 Ibid; also see Supplement to The Operative, January 3.

53 Hughes, op. cit., p. 11. Also see G. Howell, "The Engineers" Strike and Lock-Out, 1851-2", in: R. and E. Frow and M. Katenka, Strikes: A documentary history (London, 1971 ), p. 57.

54 The Times, January 1, 1852.

55 Burgess, "Trade Union Policy", pp. 646-50, provides an account of some of these earlier disputes.

56 Hughes, op. cit., p. 6. 
canvassing opinion on these questions. ${ }^{57}$ The result was staggeringly conclusive.

For the abolition of systematic overtime 5,297. Against 18.

For the abolition of piece-work 5,709. Against $16 .{ }^{58}$

This vote was swiftly followed by unilaterial action on the part of Manchester branches which succeeded in abolishing systematic overtime in the largest Manchester firms from November $1 .^{59}$ In the face of these developments the Executive's reticence crumbled. Buoyed up by this unanimity and persuaded of the apparent practicality of such claims, on November 20 they passed the following resolution: "That all engineers, machinists, millwrights, smiths and pattern-makers cease to work systematic overtime and piece work after the 31 st December, 1851."60 On November 24 two circulars $^{61}$ addressed to the membership and employers respectively explaining their stand and informing them of their intentions were dispatched. The one to the employers concluded with the following passage:

Entertaining these views, and actuated by these motives, the Executive Council have decided to advise the trade generally to discontinue the practices of systematic overtime and piecework after the 31st of December, 1851, and in those cases where overtime is really necessary, in the cases of breakdowns or other accidents, all time so worked over to be charged and paid for at the rate of double time. ${ }^{62}$

The raising of trade policy to a national level transformed the nature of the challenge into a generalised threat. It was the vital element which secured employer solidarity and culminated in the lock-out.

This preliminary and deliberately uncontentious presentation of the immediate origins of the lock-out is rather deceptive. It glosses over the differing constructions placed upon these events by the contending parties. In particular, controversy raged around the issue of the so-called "illegal men" operating the self-acting machines. Certain influential figures on the employers' side insisted that the Society actively sought the dismissal of these men. For its part, the Executive Council of ASE countered with increasingly strenuous denials:

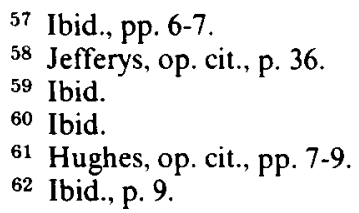


They have not demanded the discharge of unskilled workmen. They have not endeavoured to throw the skilled operative, not belonging to the Society, out of work, nor have they ever recommended others to do so. Neither have they countenanced a system of intimidation having that object. $^{63}$

The matter reached such proportions that Newton felt compelled to write in reply to an opinion expressed by Lord Cranworth. ${ }^{64}$

Once and for all we wish to say to his lordship and to all others that it is untrue that the Amalgamated Society have ever made such a demand. If they had, judgement on that point must go against them for they are clearly wrong. ${ }^{65}$

While the Executive Council was aware from the outset of the dangers implicit in the pursuance of the dismissal of "illegal men", 66 it was unable to communicate its sense of trepidation to all sections of the Lancashire rank and file. In contrast, it seems that Platt's appreciation of its propaganda potential was rather more acute.

The charge that the dismissal of "illegal men" was one of the formal demands of the ASE's present campaign was made first by Amicus in a letter to The Times. ${ }^{67}$ Notwithstanding the anonymity of this allegation it developed a momentum of its own. The Times throughout appeared utterly convinced of its accuracy. It wrote of attempts "to oppress an industrious and inoffensive class of men". ${ }^{68}$ The Manchester Employers' Association made no attempt to amend this impression. Indeed, as will be seen, some of that body actively fostered this version. But before we become more deeply embroiled in the detail of events one thing needs to be appreciated. There was no incompatibility between the claim of the employers that the Society was committed to the dismissal of "illegal men" and the union's rejoinder that this in no way constituted any part of their immediate campaign. The respective positions only clashed when the union denied that this aim had ever been an element in policy, or, alternatively, when the employers insisted that it was an immediate and formal demand in the present contest. A failure to grasp the existence of these different levels in the subtle war of words which accompanied the dispute has meant that much

63 Quoted by Hughes, op. cit., p. 25.

64 Lord Cranworth's name was floated as a possible arbiter in the dispute, but this suggestion did not meet with the approval of the Executive Council of the ASE.

65 The Operative, January $14,1852$.

66 Jefferys, op. cit., p. 35.

67 The Times, December 22, 1851. It was later revealed that this self-styled paragon of detachment was one Thomas Fairbairn, the son of the master millwright Sir William Fairbairn. Pole, Sir William Fairbairn, op. cit., pp. 323-24.

68 The Times, December 23, 1851. 
of what has been written on the origins of the lock-out is beside the point.

There is a need to scrutinise more closely some of the foregoing material and introduce some additional evidence. Prior to signing the agreement of May 16, Platt had called a meeting of Manchester employers to sound out opinion. It seemed that little more than verbal support was forthcoming. ${ }^{69}$ The only concrete development appears to have been the formation of an association of employers. It is doubtful whether Platt himself was unduly distressed at this outcome. It seems quite likely that he too did not relish an immediate confrontation. His firm was committed to a Russian contract which had to be completed before October 10 , the end of the shipping season. ${ }^{70}$ But his subsequent acceptance of his employees' terms was definitely one of tactical withdrawal rather than abject surrender. That his mood was combative rather than capitulatory is conveyed by a letter to The Times.

to prevent our being further taken advantage of in a similar manner, we have declined to enter into many contracts which we might otherwise have accepted, and have been working up our orders to prepare ourselves for what we were convinced must ultimately become inevitable, viz.: a united resistance by the employers.

Even in defeat he shrewdly laid the groundwork for a counter-offensive. As a condition of acceptance he insisted upon the insertion of an additional clause:

That if the majority of legal shops in the same line of business refuse to concede the above request, that at the end of three years from the date of these resolutions the question is again open for discussion. ${ }^{71}$

Without this clause, it was plausibly argued, "he had no guarantee that the men would make the same conditions with other employers". Granted, the information that Platt was the instigator of this codicil emanated from Newton, ${ }^{72}$ but there seems little reason to doubt its validity. It is beyond credence to suppose that once having established these conditions the men themselves might wish to reopen the matter for further debate. In any case, Platt did not subsequently deny its authorship. It may be safely surmised that by this manoeuvre Platt hoped to generalise the threat and thereby quell the competitive interests frustrating concerted employer action. The feasibility of such designs was dramatically enhanced by the decision of the ASE Executive to adopt a more direct role in initiating trade policy.

${ }^{69}$ Jefferys, op. cit., p. 36.

${ }^{70}$ The Times, January 1, 1852.

${ }^{71}$ Ibid.

72 The Times, December 31, 1851. 
On December 9, at the Clarence Hotel, a meeting of the Manchester employers unmistakably, if implicitly, distinguished between the Oldham dispute and the Society circular.

1st Resolution. - "That this meeting, having heard the statement of Messrs. Hibbert, Platt, and Sons, that their work-people intend to turn out on the 31st of December, 1851, unless all the men now working at planing machines, or tools of a similar character, are discharged, and their places supplied by mechanics belonging to a Trades' Union, the undersigned have taken this statement into consideration, and pledge themselves, should such turn out take place on this plea, either at the works of Messrs. Hibbert, Platt, and Sons, or at those of any of the undersigned, to close their establishments, and not to re-open them until agreed upon by the vote of a general meeting, and then only with work-people who have no connexion with such Trades' Union.["] $]^{33}$

This is not to argue such claims were limited solely to Hibbert and Platt. The point being made here is only that the afore-mentioned distinction was recognised. This recognition, however, did not deter the Manchester employers, following a meeting on December 16, from placing an ambiguously worded advertisement in The Times which succeeded in blurring this very distinction.

A body of persons styling themselves "The Amalgamated Society of Engineers, Machinists, Millwrights, Smiths and Pattern Makers", having made demands on several firms in this district, which are totally inconsistent with the rights of employers of labour, and would, if acceded to, preclude the exercise of all legitimate authority by the masters in their own workshops, and the same body having further given notice to one of the principal firms that unless their demands be at once conceded the workpeople in their employ will go out, or strike, on the 31 st instant. ${ }^{74}$

Following the exploits of Amicus the felt need for such sophistry receded. In a communique to a gathering of forty-six London employers on December 24 the Manchester body eschewed subtlety and openly appended the demand for the unconditional discharge of all labourers to the demands embodied in the Society circular.

A body of persons styling themselves the Amalgamated Society of Engineers, Millwrights, Mechanics, \&c. have made the following demands to the employers of this district; accompanied by a threat to one of the principal firms, that unless they are acceded to, their work-people will strike on the 31st inst.

1. The abolition of overtime, excepting in cases of break-down.

73 Hughes, op. cit., p. 12. Italics added.

74 The Times, December 20, 1851. Italics added. 
2. When overtime is absolutely necessary, it is to be paid for at double rates.

3. The abolition of the system of piecework.

4. The unconditional discharge of all labourers, or such class of persons at present engaged in working planing machines, or tools of similar character, and the employment in their stead of mechanics, members of the Union.

The report then states that the meeting went on to consider "Another communication from the Executive Council of the said Amalgamated Society, notifying to the employers of the metropolis that they 'have come to a resolution to abolish the practices of piecework and overtime,' after the 31 st of December, 1851 ". ${ }^{75}$

This statement fallaciously implies the existence of two distinct circulars, a Northern one and a Southern one. If Hughes is correct in his suggestion that initially the "Circular seems to have excited very little notice at first in the London districts", ${ }^{76}$ then this contrasts starkly with the feelings evinced following this distorted presentation of the Society's official demands. John Blyth spoke of "an attempt [.. . ] deliberately to deprive the unskilled labourer of the means of employment". John Saward moved "that the threats conveyed in the foregoing manifesto of dictation to employers and tyranny over the employed, should be promptly and peremptorily resisted". ${ }^{77}$ They formed themselves into the Central Association of Employers of Operative Engineers, and resolved "in the event of the hands of any establishment in London, Manchester, or elsewhere, going out on strike, or otherwise enforcing the demands of the Amalgamated Society on the 31 st December, 1851, or at any subsequent period, entirely close their establishments on the 10th day of January, 1852, or within one week after such other period respectively". ${ }^{78}$ Ironically, by inserting the phrase "or otherwise enforcing the demands of the Amalgamated Society", the London employers had apparently shifted from being unperturbed to a position of greater militancy than their Manchester counterparts. That the London employers were convinced as to the more far-reaching nature of the Society's Northern strategy, and no doubt fearful of the portentous implication, is confirmed by a London employer, Charles Walker. He wrote:

premising that to some of the Lancashire employers the "Amalgamated Society" went a step further, in requesting them to place articled mechanics at machines at present worked by boys and labourers. [...] [And again] placing articled men, members of the union, to work planing machines, \&c.,

75 Hughes, op. cit., pp. 14-15. Italics added.

76 Ibid., p. 11 .

77 Ibid., p. 15.

78 Ibid., p. 16. 
now in the hands of boys and labourers, [...] is not in the address to the London employers. ${ }^{79}$

On Tuesday December 30 the Lancashire Employers decided to join the Central Association in London. 80

Taken together this evidence leaves little room for doubting that the Manchester employers, or at least certain influential members of that body, skilfully and successfully contrived to misrepresent the union's official stance. The indications are that the blurring of the two issues was a deliberate ploy on the part of Platt and his accomplices to galvanise the employers into collective action and to enhance their case in the eyes of the "public". The Northern Star described the decision of the Executive Council to issue the circular as a godsend to Hibbert and Platt. It "enabled them to terrify the alarmists in to combined resistance. [...] It was a pretext which exactly suited their purpose". ${ }^{81}$ Much time and energy was expended by the union in a vain attempt to refute this falsehood. But the damage was done. The Amicus version became the prevailing one for at least the duration of the dispute.

It is at this point that both Jefferys and Burgess decide to foreclose their analysis. But the exposure of employer tactics should not be taken as a pretext for premature termination of the enquiry. Evidence of this type fails, firstly, to touch upon the issue of whether or not recourse to such tactics was engendered by fears that were genuine and deeply felt, and, secondly, whether or not these feelings had any historical foundation.

The ideological debate centred on the masters' plea, "May I not do what I will with my own?"82 Union claims to a greater say in the operation of industry were seen as "impudent" and "scandalous"; 83 as a threat to the rights of property. This was the domain of the employer, who had by dint of effort earned legal and moral title to this position of authority. The engineering employers placed their case before the public in the following terms:

79 The Times, January $9,1852$.

80 Ibid., January 1. Incidentally, Jefferys's not significant, but indicative, aside that the Manchester employers locked out their workers on January 10 in spite of the fact that the men at Hibbert and Platt had not struck work over the employment of labourers (op. cit., p. 38), is not strictly valid. By their earlier affiliation to the Central Association the resolution of the Manchester group had been superseded by the resolution of the London body (Hughes, op. cit., pp. 12, 16).

81 Northern Star, January 10, 1852.

82 Representation of the case of the Executive Committee of the Central Association of Employers of Operative Engineers, quoted by E. Vansittart Neale, May I not do what I will with my own? (London, 1852), pp. 3-4.

83 The Times, December 23, 1851. 
we must say that we alone are the competent judges of our own business, we are respectively the masters of our own establishments, and that it is our firm determination to remain so.

Ours is the responsibility of the details, ours the risk of loss, ours the capital, its perils, and its engagements. We claim, and are resolved to assert the right of every British subject, to do what we will with our own [...].

We altogether ignore the proposition that we should submit to arbitration the question whether our own property is ours; and whether we are entitled to be the master of our own actions. ${ }^{84}$

The only greater power to which the employers were prepared to pay ultimate homage was the supremacy of "natural market forces". The Times, in exasperation at the union's failure to comprehend this "obvious fact of life", wrote: "The cry of these intelligent engineers is merely the cry of the handloom weavers - a cry against inevitable and irresistible laws." 85

Such feelings were surely exacerbated by the growing impersonality of large-scale production techniques and the standardisation of process: conditions far removed from the proximity of master-operative relationships earlier in the century. The masters' claim that the union demanded the dismissal of certain "illegal men", for them, exemplified the nature of the challenge. What then of the substantive foundation of this fear? The notion that the ASE Executive Council were unswervingly opposed to the dismissal of "illegal men" accords neither with the immediate facts nor the traditional posture of the Society, or its predecessors. It is not sufficient to demonstrate that the official demands of the ASE contained no reference to the dismissal of "illegal men". Nor is it sufficient to cite the Executive's explicit and obsequious disclaimers of any such intent. What was once politic, albeit covertly so, may later become unwise. In a situation of unanticipated and escalatory confrontation the penetrating glare of unsought publicity may demand clarification; pledges of alignment or strident distantiation.

The precursor of the engineer was the millwright, a craftsman of great skill and dexterity, whose roots stretch back beyond the Norman conquest. ${ }^{86}$ The Webbs write that at the close of the eighteenth century certain groups of millwrights "possessed strong, exclusive, and even tyrannical trade societies, the chief of them being the "London Fellowship"" 87 It appears that such bodies were organised on a friendly-society basis, proffering

84 Vansittart Neale, op. cit., pp. 3-4.

85 The Times, January 12, 1852.

86 J. H. Clapham, An Economic History of Modern Britain. The Early Railway Age 1820-1850, 2nd ed. (Cambridge, 1939), p. 207.

87 S. and B. Webb, op. cit., pp. 204-05. 
mutual assistance in times of distress. While the "itinerant and often individual character of their work and terms of employment militated against a widespread organisation, [ . . .] where engine- or bridge-building was on a scale which led to regular employment in one locality, a "trade policy' emerged alongside the provision of benefits." 88

Some indication of millwright strength in London is provided by the experience of the master-millwright Sir William Fairbairn. After being engaged at Rennie's works in 1810, he was refused admission to the "Fellowship", and thus compelled to tramp out of London in search of employment in a non-union district. ${ }^{89}$ Elsewhere, Fairbairn records that the millwright's skill and status "were apt to make him vain; and with a rude independence he would repudiate the idea of working with an inferior craftsman, or even with another so skilled as himself, unless he was born and bred a millwright". ${ }^{90}$ The introduction of the steam engine and the rise of the "engineers" economy" brought the exclusive position of the millwright under increasing attack. But this did not so much presage the decline of craft privilege as its re-emergence in a modified form. Inspired by the tradition and organisational experience of the old millwright, and fortified by the acute shortage of skilled labour, the new breed of artisans in the engineering trades ${ }^{91}$ successfully strove to inherit the mantle of sectional privilege.

It may prove useful to refer to some of the material presented by Jefferys on the early engineering trade unions. The insights he provides into the traditional exclusiveness of these bodies rests uneasily alongside his later indignant repudation of the accusation that the ASE Executive might have acquiesced in, or actively sought, the dismissal of "illegal men".

The immediate predecessor and mentor of the ASE was "The Journeymen Steam Engine and Machine Makers Society", otherwise known as the "Old Mechanics". Its constitution was adopted as the basic blueprint of the Amalgamated Society. While the "Old Mechanics" had no definite trade policy, " "the main efforts of the Society were concentrated on removing

\footnotetext{
88 Jefferys, op. cit., p. 10.

${ }^{89}$ S. and B. Webb, op. cit., p. 84, note to p. 83.

90 Sir William Fairbairn, A Treatise on Mills and Millwork (London, 1861), Preface.

${ }^{91}$ The source of this new class of worker is not entirely clear. Some evidence and opinion suggests that the millwright continued, in spite of the adverse circumstances, to defend his position, while other material indicates that he reluctantly adapted to the new conditions. It would be strange had not the frustrated inventors and engineering employers made strenuous efforts to tap and channel the skills of the millwright into the techniques demanded by the new manufactures, but this source could hardly meet the needs of expanding industry.
}

92 Jefferys, op. cit., p. 21. 
the surplus engineering labour from the market by opposing systematic overtime, shortening hours, refusing to allow 'illegal' men to enter the trade and keeping the number of new entrants through apprenticeship to the standard regulation of the trade [...]'."93 The continuity of thought between the old and the new is clearly seen in the trade-protection resolutions adopted by the Birmingham amalgamation conference of September 1850: "systematic overtime was to be repudiated and any exemption decided by the District Committees; the number of apprentices was to be restricted to the proportion of one apprentice to four journeymen; the [...] system of piece-work, as it was then operated, was to be resisted." Jefferys adds that "A fourth policy, though unwritten, was fully accepted and operated by the members; it was opposition to 'illegal' men, men who had not served their time or seven years at the trade, using the tools of skilled workers."94

The engineering trade unions held aloof from the mass movements of the 1830's and 1840's. When, in 1842, the General Secretary of the "Old Mechanics", Robert Robinson, was so "ill-advised" as to lend the Society's name in support of the "Plug Riots", he was officially censured for his "impropriety of conduct during the Late Excitement". This was quickly followed by the insertion of a rule which prevented any member claiming benefit if he had been dismissed from his employment because of involvement in "any Political or Popular Movement". 95

If exclusiveness and insularity were the dominant traits of these trade societies, the defence and advance of privilege was invariably ringed by official exhortations, "deeply imbued with the necessity of caution". 96 There were, of course, very cogent reasons for circumspection. The legal position of these societies was still precarious and their funds still extremely vulnerable. Perhaps the clearest illustration that stealth was the order of the day is indicated by the aftermath of a strike at Jones and Potts of Newton-le-Willow in August 1846. While the "Old Mechanics" did not give its backing to the men, it did issue an appeal for voluntary subscriptions. Eventually, the masters had recourse to the law. A number of men were arrested, one of whom had in his possession a letter which implicated Henry Selsby (General Secretary of the "Old Mechanics"), in the collection and distribution of strike funds. This was taken as sufficient grounds for his arrest. ${ }^{97}$ Cognisant of the fragile basis of its legal status and fearful of the damage to the Society posed by a repetition of the Selsby affair, the

$\begin{array}{ll}93 & \text { Ibid., p. } 24 . \\ 94 & \text { Ibid., p. } 34 . \\ 95 & \text { Ibid., p. } 22 . \\ 96 & \text { Ibid., p. } 34 . \\ 97 & \text { Ibid., p. } 26 .\end{array}$ 
next Delegate Meeting passed the following resolution: "The Executive Council or General Secretary shall not engage in any misunderstanding between employers and employed seeing that such interference is so injurious to the interests of our Society and calculated to involve the members in legal proceedings."

And it was laid down that if a strike did occur then the Society was to place the telescope to its blind eye, and the conduct of the strike was to be placed in the hands of a committee entirely apart from the Executive Council and General Secretary of the Society. ${ }^{98}$

But for all its weight this background evidence remains essentially circumstantial. To establish how union activities prior to the lock-out might have been directly interpreted in this light by the Manchester employers, one needs to return to the events at Oldham. In particular, there is a need to re-examine the part played by the executive member William Newton. Jefferys fails to probe his role in any depth, while Burgess seems oblivious of his existence..$^{99}$ Newton replied to the Amicus charge by denying that the discharge of "illegal men" was any part of Society policy:

The council of the Amalgamated Society had nothing whatever to do with that dispute [Hibbert and Platt]; it did not originate with them. It never received their sanction. [ . . . T The agreement was a private one. ${ }^{100}$

At a public meeting of two thousand people ${ }^{101}$ in Threadneedle Street he disavowed all intentions of removing any person at present in employment; "there was nothing in the present proceedings of the Council that expressed or implied any such intention". ${ }^{102}$ This led Amicus ${ }^{103}$ with Platt's more surreptitious backing ${ }^{104}$ to claim that this denial was patently false, particularly since Newton himself had been the architect-in-chief of the May 16 settlement at Hibbert and Platt's. In response, Newton held his involvement in these negotiations was in the first place at the behest of the employees, ${ }^{105}$ and, secondly, that he had acted in a private capacity and

98 Ibid., p. 27.

99 While receiving no mention in Burgess's paper on the lock-out, Newton does make a fleeting appearance in his coverage of the affair in his subsequent book, The Origins of British Industrial Relations (London, 1975), p. 23.

100 The Times, December 29, 1851.

101 Jefferys, op. cit., p. 38.

102 The Times, December 31, 1851. Incidentally, in his strenuous efforts to refute charges of exclusiveness, Newton rather indiscreetly accused Amicus of resorting "to terms of abuse worthy of an irritated cabman". Ibid., January 7, 1852.

103 Ibid., December 27, 1851.

104 Ibd., January 1, 1852.

105 Ibid., December 29, 1851. 
not as a councilman. ${ }^{106}$ Moreover, far from being the instigator of the agreement, he had throughout endeavoured to act in a moderate manner, urging compromise on the men and an acceptance of Platt's counter-proposals. ${ }^{107}$

Newton's account of these proceedings is unconvincing in a number of areas. There is no doubt that his intervention was initially requested by the men because of his reputation in trade-union circles. On May 7 Newton attended a meeting of the men. He advised them against a strike and in favour of sending a deputation to Platt. On reporting back he was criticised for agreeing "too readily" to Platt's propositions. ${ }^{108}$ Of crucial importance is the nature of these proposals. Jefferys reports that Platt made the following concessions: "there were urgent Russian orders pending - but on the employment of labourers he would promise nothing before the following spring or summer, and agreed to remove them then only if his competitors were forced to do the same." 109

Thus, it seems that while Newton turned his face against the resolutions of the men, the divergence was one of timing rather than principle. Regarding the question of Newton's status in these negotiations, the evidence suggests that it was not constant. It is not clear when the transformation occurred, but it is apparent that, in contrast to the informality of his entry, his position on May 13 was officially endorsed. On that day he was appointed to lead an official deputation to Oldham with a view to reconciling the differences between the employers and the men. Agreement was finally reached on May 16. Platt accepted that the "illegal men" would be dismissed by Christmas 1851 , but he insisted upon the insertion of the previously cited clause. So, Newton, in his official capacity, gave his name to an agreement embodying not only the dismissal of "illegal men" at a specific firm, but also indicated a long-term intention to generalise this condition. He affirmed:

when they had settled the question as far as Mr. Platt was concerned, they might extend their influence, under this example, to other manufacturers, until the machines become generally in the hands of skilled workmen. ${ }^{110}$

That this was no empty statement is shown by the activities of Hemm, another member of the official Oldham deputation. Drawing on the Hibbert and Platt experience, he negotiated a very similar agreement at the

\footnotetext{
106 Ibid., January 2, 1852.

107 Ibid., January 9.

108 Ibid., December 29, 1851.

109 Jefferys, op. cit., p. 35.

110 The Operative, May 17, 1851.
} 
works of Parr, Curtis and Madeley. On the question of the discharge of the men operating the planing machines, it seems Hemm expressed the view that their dismissal would not be required until "the end of the year, when Messrs. Hibbert, Platt, and Sons and other employers, had agreed to substitute mechanics instead of labourers". ${ }^{111}$

The Executive Council of the ASE did not subsequently denounce the Hibbert and Platt settlements as incompatible with the principles of the Society. In any case the May 13 Executive minutes clearly show that the Council's intention in sending the deputation to Oldham was to urge the acceptance of Platt's proposals concerning the dismissal of the "illegal men". Any remaining doubts surrounding the Council's position are finally squashed by an Executive resolution of December 28:

The enforcement of the request of the Oldham workmen that Mr. Platt should discharge the men from the machines would endanger the carrying of other and more important measures in the trade and would tend to strengthen the agitation of the employers to create public feeling against our Society, we therefore instruct the members of Oldham not to leave their situations if Messrs. Hibbert and Platt refuse to carry out the agreement. ${ }^{112}$

This demonstrates that no principle was at stake, the argument is one of tactical expediency. To say the least, serious doubt is cast upon Burgess's view that there exists "little evidence to suggest that other members of the Executive [in addition to Newton] like the General Secretary, William Allan, supported the demand for the dismissal of illegal men from machines". ${ }^{113}$ It is clear that both Newton and the Executive Council were quite prepared to acquiesce in agreements ousting "illegal men", but they were not willing to set the pace, and they were certainly not prepared to adopt the sort of public stand on the issue a strike at such a prominent works would undoubtedly entail. The Society's posture is neatly, if unwittingly, captured by an ASE member from London:

I was not aware from anything I have heard at our meetings that the discharge of those men, not mechanics, who are working at machines was demanded, but I know we take great pains to prevent such men being put to machines. ${ }^{114}$

\section{Conclusion}

It is rather easy, depending upon one's ideological proclivities, to score

111 The Times, January 1, 1852

112 Jefferys, op. cit., p. 38.

113 Burgess, op. cit., p. 23.

114 The Times, December 27, 1851. 
points by highlighting either the prevarications of Newton and the Executive or, alternatively, the employers' acquiescence in the Platt-Amicus deception. To engage in such one-sided appraisals, as do Pelling, Jefferys and Burgess, only serves to confirm that they too are no less susceptible to the types of pressures and commitments that beset the original protagonists, and of which they are so selectively intolerant. The respective positions adopted by these historians resound like echoes from the past. They are little more than the authentic replication of the disputation of the day, each one taking up the cudgels on behalf of his own chosen ally. They contrive to present the objects of their allegiance as the wounded party. The desire to understand runs a lame second to the greater goal of defending the faith and apportioning blame. Consciously, or otherwise, their minds must have been ideologically predisposed to certain evidence, and firmly set against the entry of other material. No other interpretation begins to explain the flagrant bias displayed by these accounts. Even when, as is the case with Jefferys, some countervailing evidence slips through, he is no longer psychologically disposed to handle it. It merely hangs around; extraneous detail in search of a more adequate conceptual framework.

It only remains to probe the reasons for the inadequacy of these previous accounts. These historians are engaging in a method of analysis common, not to say widespread, in the social sciences. They are applying an idealised notion of "how they believe things should be" as a comparative tool by which to judge actual social forms. In most historical accounts the criterion of selection and the ideal it serves remains implicit, if not unconscious. To lay bare the idcology one is compelled to scan the text for clues.

Consider first Henry Pelling's History of British Trade Unionism. This work is teleologically conceived on the premise that there is an immanent historical movement towards social integration via the institutionalisation of conflict and, moreover, that this process is to be welcomed. Throughout, he is absorbed by the current prestige of the trade-union movement, and its acceptability to the government and the public. ${ }^{115}$ Because they threaten this vision, unofficial strikes ${ }^{116}$ and the Communist Party, ${ }^{117}$ for example, are perceived as being "problems". Pelling's bias emerges continuously.

115 This preoccupation is perhaps most clearly expressed when he laments the treatment meted out to Robert Applegarth, a leading member of the "Junta", by his own union. It seems his union refused to allow him time off to perform his duties as a Commissioner of the "Royal Commission on Contagious Diseases". In consequence, he resigned his union membership. Pelling comments: "To be forced out of the movement in this way was a sad fate for a man who had contributed more than anyone else to making unionism acceptable to the public opinion of the upper classes." Pelling, op. cit., p. 73. Italics added.

116 Ibid., p. 215.

117 Ibid., p. 227. 
There can be little doubt as to which elements he favours in the ASE. He writes: "Newton was active in urging the adoption of his plans for cooperative workshops. [. . . ] it was perhaps fortunate for the Society that its general secretary was not Newton, but the more cautious Allan, who gradually built up the funds on conservative lines." ${ }^{118}$ Pelling is nothing if not consistent in his prejudice over time: "The A.E.U. also had a strong Communist element among its officials [...]. [But the] problem of Communist penetration [ . . ] only became acute in 1947 ". ${ }^{119}$ He concludes the study by stressing the importance of the "task of reforming union structure [. . .], and of bringing official union organization to the worker on the shop floor". 120

The examples of prejudice are legion, but the above will have to suffice. They clearly bring out his normative bias. Thus, his unequivocal embrace of the employers' version of the issues precipitating the lock-out was no chance happening. Nor was it the outcome of a careful weighing of evidence. Rather, it was a consequence of his general value orientation. Given his commitment to trade-union respectability and the steady institutionalisation of conflict, one would be unlikely to find him favourably disposed to any industrial action smacking of a harassed Executive leading from behind. In a word, he stands so close to the dominant value system that his powers of appraisal are seriously impaired.

It would be difficult to read Jefferys's Story of the Engineers without gaining the distinct impression that it was conceived and presented as a celebration of the Society - its growth, its temporary setbacks and its victories. This is not to say the account entirely lacks a critical dimension. However, the criticism does tend to be reserved for attitudes and behaviour which divert the union from that path which is perceived as being the one most likely to ensure that the trade-union movement will eventually assume its "rightful place" in society. But, as has been seen, the contrast between his account of the factionalism and insularity of the early engineering unions and his treatment of the lock-out, involving, as it does, the denial that sectional privilege was a crucial issue, is very difficult to reconcile. Seemingly, he is only able to accomplish this act of mental agility because, in the latter case, his gaze is unflinchingly fixed on the formal demands of the Society, to the exclusion from memory and vision of all contrary evidence. On other occasions, he is quite prepared to discuss what are taken to be the detrimental effects of craft exclusiveness when it is seen

120 Ibid., p. 260. 
to engender intra-class strife. But such considerations weigh lightly when the conflict assumes inter-class proportions.

The surface indicators of this general malaise are less apparent in the work of Burgess. In The Origins of British Industrial Relations he adopts as his theoretical standpoint a rather crude Marxist position. He writes: "In industrial relations, it is clear that change stems from the contradiction between legal fiction and social reality inherent in the wage contract. The obvious disparity between the buyers and sellers of labour makes conflict inevitable. But the survival of capitalist society requires a resolution of conflict, which becomes the task of industrial relations." 121 Without probing the incongruities of the above passage, it is, of course, quite legitimate to examine the adequacy of such an approach. However, one needs to guard against selecting only that material which is supportive of this position. As we have seen with his treatment of the lock-out, and in particular his depiction of the employers as the sole "misrepresenters of the facts", he does fall prey to this temptation. This kindles the suspicion that he is not so much testing a perspective as defending a vision of how trade unions "should develop". These fears are confirmed when one sees evidence which veers against this commitment being either neglected or treated in a disdainful manner.

Of the internal battles that beset the ASE in the late decades of the nineteenth century between the "old guard" and the "forward members" concerning the issue of sectional privilege versus industrial unionism, Burgess uncritically cites a view he attributes to the work of Roland Smith: "The district committees of the ASE remained the focus of collective bargaining, despite the clear need for policy-making on a genuinely industrial basis." 122 Burgess links this "need" to "the interests of engineering workers as a whole". ${ }^{23}$ Another threat to what he seems to perceive to be "the promise of industrial unionism" was inter-union conflict. This time, opting not to shelter behind a supportive statement, he writes: "One disturbing feature of the industrial relations scene in the 1890 s was the interunion dispute."124 Thus, while Burgess does not so ostensibly allow his political commitments to intrude, their influence is just as sure.

Whether these historians be partisans masquerading as detached observers, or entirely candid about their affiliations, is of little consequence. What is beyond peradventure is the pernicious way in which their political inclinations have come to hamper and distort their critical faculties.

121 Burgess, op. cit., Introduction, p. iv.

122 Ibid., p. 48. Italics added.

123 Ibid., p. 47.

124 Ibid., p. 49. Italics added. 
Despite their ideological polarity, Pelling, Jefferys and Burgess do tread common methodological ground. All three hold to an idealised notion of how trade unions "should develop". They employ their respective models as comparative tools by which to judge actual social forms. Their selection and interpretation of material is guided by the precepts of these visions. Only that evidence conducive to their maintenance is perceived, while any material which threatens the ideal apparently goes unseen. One is not arguing that selectivity is bad; it is, of course, unavoidable. What is deprecated is selectivity in the cause of an ideal, rather than selectivity guided by the desire to more fully comprehend social phenomena. As long as political and theoretical concerns remain so inexorably wedded, grave limitations are imposed upon the potential of one's theoretical perspective, and, incidentally, on the pragmatic level, upon the viability of any programme for political action based on such resultant studies. 